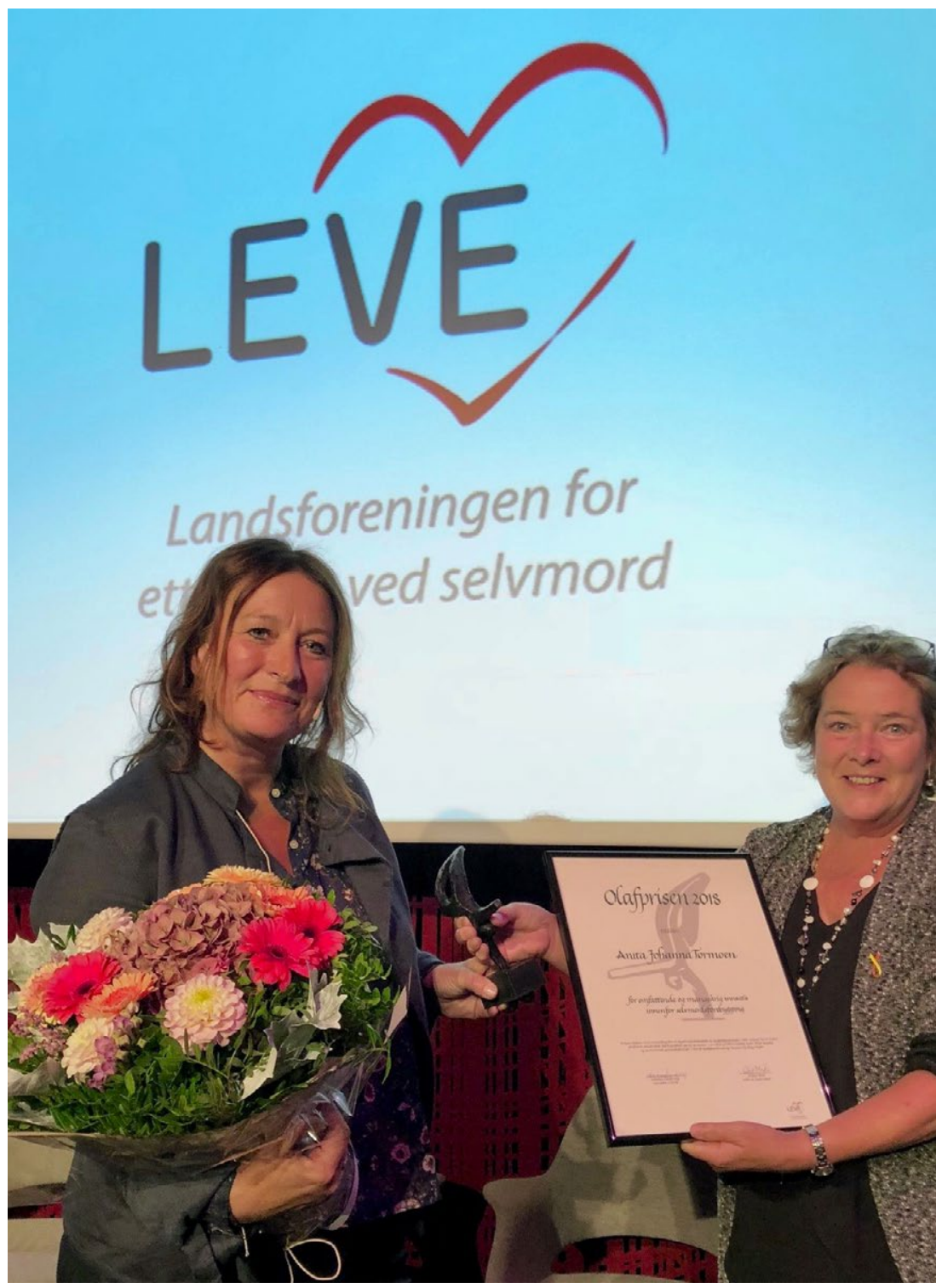

\title{
Olaf-prisen
}

Olaf-prisen (tidligere Olafs Minnepris) er etablert av stiftelsen Olafs Minnefond til forebygging av selvmord blant unge. Prisen tildeles som en anerkjennelse til en person som har bidratt med fremragende vitenskapelig arbeid eller kunnskapsformidling innenfor feltet selvmordsforebygging blant barn og ungdom.

Olaf-prisen er en hederspris som deles ut til en person som har gjort en særlig innsats innenfor forskning eller kunnskapsformidling for å forebygge av selvmord. Tidligere prisvinnere omfatter bl.a. forfattere, journalister og fagfolk som jobber med selvmordsforebygging.

Vurderingen av aktuelle kandidater skal i første rekke bygge på deres nyere forsknings- eller formidlingsbidrag. Ved tildelingen skal det legges særlig vekt på kandidatenes faglige selvstendighet, deres evne til nyskaping og på arbeidets praktiske betydning for forebygging av suicidal atferd blant barn og ungdom.

Innstilling av kandidater til prisen gjøres av et fagutvalg bestående av Erlend Mork (leder), Kari Wille Rekdal, Berit Grøholt og Reidun Kjelling Nybø.

\section{Olaf-prisen 2018 til Anita Johanna Tørmoen}

LEVE OG RøDE KORS holdt mandag 3. september sitt årlige selvmordsforebyggende seminar på Litteraturhuset i Oslo, i anledning Verdensdagen for selvmordsforebygging. Tema for kvelden var betydningen av tilhørighet og å ha et språk for smerte.

Førsteamanuensis ved NSSF, Anita Johanna Tørmoen, fikk Olaf-prisen for forebygging av selvmord blant unge. Tørmoen har igiennom mange år arbeidet for å spre kunnskap om hva som kjennetegner og hielper ungdom med vedvarende forhøyet selvmords- risiko. Prisen fikk hun for sitt bidrag som forsker og kliniker til å hjelpe ungdom, og for å giøre forskning klinisk relevant.

På Litteraturhuset snakket psykolog Gry Stålsett fra Modum bad om behovet for tilhørighet og eksistensiell nød i vår tid, og Oddvar Vignes delte sine erfaringer. Psykiater Finn Skårderud ledet sofaprat med Vignes, Rita Småvik (RVTS Midt), Đystein Ringen Kristoffersen (samtaletjenesten Kors på halsen) og Anniken Bakken Lundberg. 